\title{
The early effects of afforestation on biodiversity of grasslands in Ireland
}

\author{
Erika Buscardo • George F. Smith • Daniel L. Kelly · Helena Freitas • \\ Susan Iremonger · Fraser J. G. Mitchell · Saoirse O'Donoghue • \\ Anne-Marie McKee
}

Received: 30 October 2006/ Accepted: 23 October 2007/Published online: 8 February 2008

(C) Springer Science+Business Media B.V. 2008

\begin{abstract}
The target rate of afforestation in Ireland over the next 30 years is 20,000 ha per year, which would result in an increase of the forest cover from the current $10 \%$ to $17 \%$. In order to promote sustainable forest management practices, it is essential to know the composition and conservation value of habitats where afforestation is planned and the effects of subsequent planting upon biodiversity. The objectives of this study were to investigate changes in vegetation composition and diversity of grasslands 5 years after afforestation with Sitka spruce (Picea sitchensis) and determine the primary ecological and management factors responsible for these changes. Species cover, environmental and management data were collected from 16 afforested and unplanted improved and wet grassland site pairs in Ireland. Our results indicate that 5 years after tree planting, there were significant changes in richness, composition, and abundance of species. Competitive and vigorous grasses were more abundant in planted than in unplanted sites, as were generalist species found in both open and wooded habitats, while small-stature shadesensitive species were less abundant. Vascular plant species richness and Shannon's diversity index were higher in unplanted wet grassland, than in the planted sites. Bryophyte species richness was higher in planted improved grassland than in unplanted sites. The differences were primarily the result of the exclusion of grazing, ground preparation, changes in nutrient management and drainage for afforestation. Drainage ditches provided a temporary habitat for less competitive species, but the overall effect of drainage was to reduce the diversity of species dependent on wet conditions. Variance partitioning showed differences in the relative influences of environmental and management variables on biodiversity in the two habitats, probably due to the greater pre-afforestation grazing pressure and fertilisation levels in improved grasslands. The differences in biodiversity
\end{abstract}

\footnotetext{
E. Buscardo · G. F. Smith · D. L. Kelly · S. Iremonger · F. J. G. Mitchell · S. O’Donoghue A.-M. McKee BIOFOREST Project, Department of Botany, School of Natural Science, Trinity College Dublin, Dublin 2, Ireland

E. Buscardo $(\bowtie) \cdot$ H. Freitas

Centre for Functional Ecology, Department of Botany, University of Coimbra, 3001-456 Coimbra, Portugal

e-mail: erikatea@ci.uc.pt
} 
between planted and unplanted grasslands indicate that afforestation represents a threat to semi-natural habitats where distinctive and highly localised plant communities could potentially occur.

Keywords Afforestation · Biodiversity · Grassland · Ordination · Plantation · Variation partitioning

$\begin{array}{ll}\text { Abbreviations } \\ \text { CCA } & \text { Canonical correspondence analysis } \\ \text { Dbh } & \text { Diameter at breast height }(1.3 \mathrm{~m}) \\ \text { TVE } & \text { Total variation explained } \\ \text { IG } & \text { Improved grassland } \\ \text { WG } & \text { Wet grassland } \\ \text { TI } & \text { Total inertia }\end{array}$

\section{Introduction}

In most European countries, large areas of land are being converted from agriculture to forestry (Elemans 2004; Wulf 2004). In Ireland, afforestation of agricultural land is progressing at one of the highest rates in Europe (MCPFE 2003). The government objective is to increase the country's forest cover from its current level of approximately $10 \%$ to $17 \%$ by 2030 to create a forest industry of sufficient scale to meet economic and social targets (Department of Agriculture Food and Forestry 1996; Forest Service 2000). This proposed large-scale and rapid expansion of forestry will alter the landscape radically in many parts of the country, with significant implications for biodiversity.

The net effects of afforestation will depend on the biodiversity of the new forest and on that of the habitat it replaces. Afforestation of improved grasslands may be of net benefit to biodiversity, particularly in intensively managed landscapes. However, it is likely that afforestation is mostly being carried out on the less agriculturally productive land (Heritage Council 1999). The most ecologically interesting grasslands are semi-natural communities that are long established and usually species-rich (Byrne et al. 1997). Recent survey work in eastern Ireland shows that semi-natural grasslands exist as isolated fragments within an intensively farmed landscape (Byrne et al. 1997). Most semi-natural grasslands lack formal nature conservation designations that preclude afforestation; therefore, sites of high biodiversity value could potentially be planted. Changes in grassland management, including afforestation, may induce corresponding changes in the structure of the vegetation or plant species composition (Alard et al. 1994). The conservation of semi-natural grasslands will depend therefore on the awareness at the planning stage of the effects the proposed forest will have on them and the surrounding area.

Most research on the effects of afforestation on understorey plant communities focuses on the mature stages of plantation development and emphasises the role of forest structure, particularly canopy cover (Hill and Jones 1978; Hill 1979; Sykes et al. 1989; Wallace et al. 1992; Wallace and Good 1995; Fahy and Gormally 1998; Ferris et al. 2000; French 2005). In contrast, early changes in composition and structure of vegetation following afforestation have received comparatively little attention. The vegetation of planted areas is influenced by the cessation of agricultural practices, such as grazing, burning, liming and fertiliser application, and by forest establishment operations, notably land drainage, 
ploughing or other ground preparation, and tree planting (Wallace et al. 1992). For example, cessation of grazing often results in the loss of several species from plant communities in the face of competition from a restricted range of aggressive grasses such as Molinia caerulea and Festuca rubra (Welch and Rawes 1964; Ball 1974). Other vegetation changes may be due to some of the changes in soil properties reported from pastures converted to plantations (Parfitt et al. 1997; Alfredsson et al. 1998; Jobbàgy and Jackson 2003, 2004; Farley and Kelly 2004). After plantation, grassland communities are progressively replaced by species characteristic of shady environments, notably bryophytes, and species of disturbed soils, especially rushes and grasses (Hill and Jones 1978; Hill 1979; Wallace et al. 1992; Ferris et al. 2000; French 2005). Afforestation of upland vegetation replaces specialised associations which are present at both extremes of the fertility gradient with less distinctive communities in which generalist species preponderate (Wallace et al. 1992), and it is likely that afforestation has a similar impact on lowland grasslands. However, the extent to which changes in forest structure or changes in land management at the early stages of afforestation are responsible remains unclear. Better understanding of the relative importance of different factors influencing understorey plant diversity will inform decisions on whether to plant particular habitats or sites. It will also improve biodiversity management in existing forests and inform efforts to restore open habitats in former plantation forests.

Given recent increases in the rate of afforestation, the paucity of previous studies and the potential for significant biodiversity loss, there is a need for research to determine the effects of land use change from grassland to coniferous plantation forest. The objective of this study was to investigate the effects of afforestation on the composition and structure of species assemblages and the relationships of the changes observed with ecological and management factors. The patterns of variation in biodiversity and soil properties were assessed in 16 recently afforested sites and 16 non-afforested equivalent habitats in two vegetation types, improved grasslands and unimproved wet grasslands.

\section{Materials and methods}

\section{Study sites}

Sixteen pairs of sites were selected in two habitat types that are commonly used for afforestation: eight improved agricultural grasslands and eight unimproved wet grasslands (Fig. 1). The first is characterised by intense management, subjected to fertilisation (ground rock phosphate, artificial $\mathrm{N}$ and N-P-K fertiliser) and heavily grazed or used for silage making, while the second is used for generally less intensive livestock grazing and is subjected to a lower fertilisation rate than improved grasslands. The site locations were selected to encompass the geographic and environmental range occupied by these grassland types in Ireland. The grasslands were defined according to a broad classification scheme developed by the Heritage Council (Fossitt 2000). Improved grasslands were typically dominated by Lolium perenne and Trifolium repens. Wet grasslands included oligotrophic sites characterised by Molinia caerulea, Juncus acutiflorus and Agrostis canina and more base-rich sites characterised by such species as Carex hirta, Iris pseudacorus and Filipendula ulmaria. Each pair of sites consisted of one pre-afforestation site and one post-afforestation site, which were geographically (usually adjacent) and environmentally matched. The planted sites were comprised of 5 year old forest of Sitka spruce (Picea sitchensis), the most commonly planted species in Ireland (Forest Service 


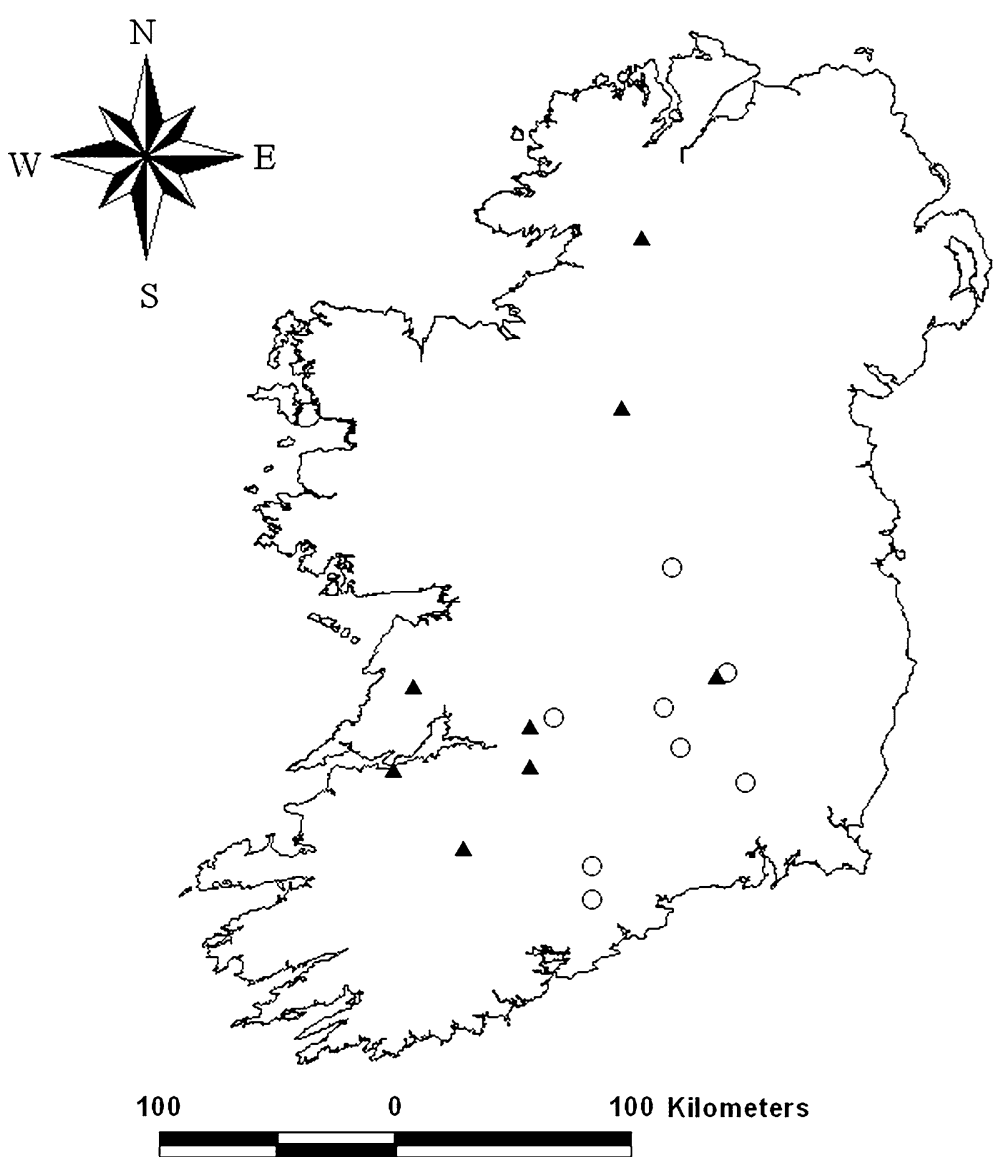

Fig. 1 Map of Ireland showing the geographical location of the 16 site pairs. $\bigcirc$ indicates improved grasslands, $\boldsymbol{\Delta}$ indicates unimproved wet grasslands

2004), often mixed with a smaller amount of Japanese larch (Larix kaempferi). The improved grasslands were mostly on brown earth soils, with two site pairs on brown podzolics. Wet grasslands were located on gley soils with mull humus.

Data sampling procedure

Fieldwork was conducted during the summers of 2002 and 2004. In each site three plots $(10 \mathrm{~m} \times 10 \mathrm{~m})$ were surveyed. All plots were orientated with the corners at the four cardinal points of the compass. Within each $10 \mathrm{~m} \times 10 \mathrm{~m}$ plot, two smaller subplots measuring $2 \mathrm{~m} \times 2 \mathrm{~m}$ were placed at opposite corners perpendicular to the slope. In afforested sites, plots were placed so that the $4 \mathrm{~m}^{2}$ plots did not include any drainage ditches. Within each $100 \mathrm{~m}^{2}$ plot the presence of all vascular plant species was recorded as well as the presence of bryophytes forming patches more than $50 \mathrm{~cm}^{2}$. Species that dominated the vegetation were noted, but no other abundance data were collected. The average height and percent cover of vegetation in each of several layers/growth-form 
categories were recorded: saplings, shrubs (as defined by growth form), field layer (herbaceous vegetation, including ferns) and ground layer (mosses and liverworts). Also recorded were the percent cover of bare soil or rock, percent cover of litter and percent cover of standing water. For every $4 \mathrm{~m}^{2}$ subplot a list of vascular plant and bryophyte species was made and their percentage cover estimated to the nearest $5 \%$. Below $5 \%$ two additional cover-abundance categories were distinguished: (a) $3 \%$ and (b) $0.5 \%$. For all bryophytes only species forming patches more than $5 \mathrm{~cm}^{2}$ were recorded. For each $2 \mathrm{~m} \times 2 \mathrm{~m}$ subplot, we recorded height and percentage cover of each of the four vegetation layers listed above and height and diameter at breast height $(\mathrm{dbh}-1.3 \mathrm{~m})$ of each sapling occupying 5\% or more of the plot (dbh was not recorded for trees $<2 \mathrm{~m}$ tall).

The nomenclature of vascular plants, mosses and liverworts follows Stace (1997), Smith (2004) and Paton (1999) respectively.

For each $10 \mathrm{~m} \times 10 \mathrm{~m}$ plot the following environmental and management data were recorded: latitude, longitude, slope, aspect (degrees), elevation, soil drainage (3-point scale: poorly-, moderately- or well-drained), grazing intensity (4-point scale: from 0 , no sign of mammal grazing to 3, heavy grazing), recreational use (3-point scale: 0 , no sign of human impact; 1 , sign of low-impact human presence; 2 , high impact human recreational use), presence or absence of drainage ditches and other aspects of site management. Aspect was transformed to a linear scale such that southwest aspect was assigned a value of 1 , northeast aspect was assigned a value of 0 and northwest and southeast aspects had a value of 0.5 :

$$
\text { If } 0 \leq x \leq 225 \rightarrow x^{\prime}=\frac{|x-45|}{180} ; \text { if } 226 \leq x \leq 360 \rightarrow x^{\prime}=\frac{405-x}{180}
$$

where $x=$ aspect and $x^{\prime}=$ transformed aspect.

Soil samples were collected from each $10 \mathrm{~m} \times 10 \mathrm{~m}$ plot to a depth of $10 \mathrm{~cm}$. Each sample was comprised of nine evenly spaced subsamples. Soil $\mathrm{pH}$ was determined on fieldmoist samples using a glass electrode on a 2:1 distilled water:soil suspension. Soil samples were air-dried and analysed for: total $\mathrm{N}$ by Indophenol Blue method (Berthelot 1859) with colorimetric detection at $630 \mathrm{~nm}$, total orthophosphate $\mathrm{P}$ by the Molybdenum Blue method (Murphy and Riley 1962) with colorimetric detection at $880 \mathrm{~nm}$, and total $\mathrm{Ca}, \mathrm{Mg}$ and $\mathrm{K}$ by Atomic Absorption Spectroscopy using a Varian SpectrAA 400. Organic matter content was determined by loss on ignition. Soil element percentages were converted to $\mathrm{mg} / \mathrm{L}$ after calculation of bulk density following the method of Jeffrey (1970). Adjacent to one of the $100 \mathrm{~m}^{2}$ plots in each site, a $30 \mathrm{~cm}$ deep soil pit was dug, the soil profile was sketched and the soil type determined according to the Irish classification (Gardiner and Radford 1980).

\section{Data analyses}

The floristic data were analysed using Canonical Correspondence Analysis (CCA) (ter Braak 1986) on $4 \mathrm{~m}^{2}$ subplots (82 and 126 species for improved grasslands and unimproved wet grasslands, respectively) employing mean abundance data (obtained by averaging abundances of the two $4 \mathrm{~m}^{2}$ subplots located in each $100 \mathrm{~m}^{2}$ plot). Separate CCAs were conducted for the two grassland types. All the planted tree species were eliminated from the vegetation records prior to analysis. Multivariate analyses were performed using CANOCO version 4.5 (ter Braak and Smilauer 2002). Forward selection was used to select significant explanatory variables. Only those significant at the $p<0.05$ level 
were included. Significant variables were divided into two groups: environmental variables and management variables. To quantify the contribution of each class of variables in explaining species composition, variation partitioning was performed using partial CCA (Borcard et al. 1992; Økland and Eilertsen 1994). Partial ordination is an important tool for studying residual variation after 'factoring out' one or more variables (Legendre and Legendre 1998; ter Braak and Smilauer 2002). This method not only allows statistical testing, but also provides a quantification of the variation explained by the different sets of variables (Økland and Eilertsen 1994). Three CCAs (the first constrained by all significant environmental and management variables, the second constrained by environmental variables only and the third constrained by management variables only) and two partial CCAs (the first constrained by environmental variables with management variables as covariables and the second constrained by management variables with environmental variables as covariables) were performed on each habitat data set $\left(4 \mathrm{~m}^{2}\right.$ subplots). Significances of the CCAs were tested using a Monte Carlo permutation test (with 499 permutations for both explanatory variables and final results) against the null hypothesis of no difference between planted and unplanted sites. Default options were employed, including the reduced model in permutation tests.

The following diversity indices were calculated for each $4 \mathrm{~m}^{2}$ subplot: vascular plant species richness, bryophyte species richness, Shannon diversity index $\left(H^{\prime}\right)$ (Pielou 1975) and the evenness index $\left(J^{\prime}\right)$, an index which describes the dominance structure of species (Smith and Wilson 1996). The mean of the two subplots was the experimental unit. Species richness was also calculated for each $100 \mathrm{~m}^{2}$ plot. Species frequency in unplanted and planted sites (using presence/absence in $100 \mathrm{~m}^{2}$ plots) was compared using the McNemar test (Sokal and Rohlf 1995) followed by the Hochberg procedure for controlling experimentwise error rates for multiple independent tests (Hochberg 1988). To test the differences in species richness, Shannon diversity index and evenness between unplanted and planted sites, paired $t$-tests were used. Soil data in planted and unplanted sites were compared using paired $t$-tests and non-parametric Wilcoxon's paired signed-ranks tests. Statistical testing was carried out using SPSS version 12.0 (SPSS 2003).

\section{Results}

\section{Species frequency}

The major aspect of the change in species frequency after afforestation of improved grassland was the increase in competitive grasses such as Arrhenatherum elatius and Festuca rubra and the drastic decrease of species of neutral pasture, including small-stature grassland herbs such as Bellis perenne, Cerastium fontanum, Ranunculus repens, Taraxacum officinale agg., Trifolium repens and grasses such as Lolium perenne (Table 1). Rubus fruticosus was completely absent from the unplanted grasslands (but abundant in the surrounding hedges) and occurred in 13 of the planted plots.

Plantations on wet grassland had higher frequencies of species of wet, disturbed conditions, such as Carex viridula and Riccardia chamedryfolia than unplanted wet grasslands (Table 2). Tall, highly competitive species like Deschampsia cespitosa and Rubus fruticosus agg. were more frequent in planted than unplanted sites, while low-growing herbs like Ranunculus flammula, $R$. repens and Trifolium repens were more frequent in unplanted plots. 
Table 1 Significant changes in species frequency (\%) between unplanted and afforested site pairs in improved grassland $10 \mathrm{~m} \times 10 \mathrm{~m}$ plots

\begin{tabular}{llll}
\hline Species & $\mathrm{UP}$ & $\mathrm{P}$ & $p$-value \\
\hline Arrhenatherum elatius & 0 & 41.67 & $* * *$ \\
Festuca rubra & 33.33 & 83.33 & $*$ \\
Potentilla anglica & 0 & 33.33 & $*$ \\
Rubus fruticosus & 0 & 54.17 & $*$ \\
Bellis perennis & 58.33 & 12.5 & $*$ \\
Cardamine spp. & 50 & 0 & $* *$ \\
Cerastium fontanum & 79.17 & 16.67 & $* * *$ \\
Lolium perenne & 100 & 20.83 & $* * *$ \\
Ranunculus acris & 41.67 & 0 & $*$ \\
Ranunculus repens & 91.67 & 33.33 & $* *$ \\
Rumex obtusifolius & 50 & 8.33 & $*$ \\
Taraxacum officinale agg. & 87.5 & 37.5 & $*$ \\
Trifolium repens & 83.33 & 16.67 & $* * *$ \\
\hline$N=24$, UP & & &
\end{tabular}

$N=24, U P$ unplanted, $P$ planted

$p$-values are the results of the McNemar test $\left({ }^{*} p<0.05,{ }^{* *} p<0.01,{ }^{* * *} p<0.001\right)$, adjusted to control for the experimentwise error rate

Table 2 Significant changes in species frequency (\%) between unplanted and afforested site pairs in unimproved wet grassland $10 \mathrm{~m} \times 10 \mathrm{~m}$ plots

\begin{tabular}{lccc}
\hline Species & $\mathrm{UP}$ & $\mathrm{P}$ & $p$-value \\
\hline Carex viridula & 8.33 & 54.17 & $*$ \\
Deschampsia cespitosa & 16.67 & 70.83 & $* *$ \\
Kindbergia praelonga & 8.33 & 50 & $*$ \\
Riccardia chamedryfolia & 0 & 29.17 & $*$ \\
Rubus fruticosus & 4.17 & 58.33 & $* *$ \\
Ranunculus flammula & 41.67 & 12.5 & $*$ \\
Ranunculus repens & 91.66 & 54.17 & $*$ \\
Senecio jacobaea & 33.33 & 0 & $*$ \\
Trifolium repens & 66.67 & 29.17 & $*$ \\
\hline N & & &
\end{tabular}

$N=24, U P$ unplanted, $P$ planted

$P$-values are the results of the McNemar test $\left(* p<0.05,{ }^{* *} p<0.01\right)$, adjusted to control for the experimentwise error rate

In both the habitat groups there were no significant differences in mean vascular plant species richness in $100 \mathrm{~m}^{2}$ plots between planted and unplanted sites according to paired $t$-tests. Vascular plant species richness was significantly higher in unplanted $4 \mathrm{~m}^{2}$ subplots of unimproved wet grassland (Table 3). Bryophyte species richness in $100 \mathrm{~m}^{2}$ plots was significantly higher in planted improved grassland than in unplanted sites. Evenness was somewhat higher in improved grassland planted subplots $(p=0.07)$, and Shannon's diversity index was significantly lower in wet grassland planted plots.

No species in the Irish Red Data Book for vascular plants (Curtis and McGough 1988) or bryophytes listed as rare by Holyoak (2003) were found in the habitat or plot surveys. 
Table 3 Mean values \pm SEM of vascular plant species richness (VSR), bryophyte species richness (BSR), Shannon's diversity index $\left(\mathrm{H}^{\prime}\right)$ and evenness index $\left(\mathrm{J}^{\prime}\right)$ in $100 \mathrm{~m}^{2}$ plots and $4 \mathrm{~m}^{2}$ subplots in unplanted and planted sites in improved (IG) and wet grasslands (WG)

\begin{tabular}{|c|c|c|c|c|c|c|}
\hline & \multicolumn{3}{|c|}{ Improved grasslands } & \multicolumn{3}{|c|}{ Unimproved wet grasslands } \\
\hline & UP & $\mathrm{P}$ & $p$-value & UP & $\mathrm{P}$ & $p$-value \\
\hline \multicolumn{7}{|l|}{$100 \mathrm{~m}^{2}$} \\
\hline VSR & $17.1 \pm 2.0$ & $14.5 \pm 1.8$ & 0.298 & $28.9 \pm 1.7$ & $25.8 \pm 2.3$ & 0.320 \\
\hline BSR & $0.2 \pm 0.1$ & $0.96 \pm 0.2$ & 0.020 & $2.4 \pm 0.6$ & $4.1 \pm 0.8$ & 0.167 \\
\hline \multicolumn{7}{|l|}{$4 \mathrm{~m}^{2}$} \\
\hline VSR & $10.1 \pm 1.4$ & $8.0 \pm 0.9$ & 0.261 & $17.7 \pm 1.5$ & $10.9 \pm 0.9$ & 0.006 \\
\hline BSR & $0.5 \pm 0.2$ & $0.4 \pm 0.2$ & 0.336 & $2.4 \pm 0.6$ & $1.6 \pm 0.4$ & 0.485 \\
\hline $\mathrm{H}^{\prime}$ & $1.45 \pm 0.17$ & $1.44 \pm 0.14$ & 0.962 & $2.37 \pm \mathbf{0 . 0 8}$ & $2.02 \pm 0.12$ & 0.023 \\
\hline $\mathrm{J}^{\prime}$ & $0.57 \pm 0.42$ & $0.67 \pm 0.3$ & 0.070 & $0.74 \pm 0.01$ & $0.73 \pm 0.24$ & 0.415 \\
\hline
\end{tabular}

$U P$ unplanted, $P$ planted

$N=8$ site pairs in each group. $p$-values indicate the results of paired $t$-tests between site pairs, significant differences among planted and unplanted sites are indicated in bold type

However, some unplanted wet grassland communities were of high conservation value. Four sites contained communities referable to the EU Habitats Directive Annex I habitat 'Molinia meadows on calcareous, peaty or clayey-silt-laden soils (6410)' (European Commission 1999).

\section{Ordination and variance partitioning}

Twelve explanatory variables in the improved grassland subplots and eleven in the unimproved wet grassland subplots significantly explained variation in species abundances (Table 4). The most important variables accounting for variation in improved grasslands were sapling height, elevation, shrub cover and drainage ditches. The largest fractions of variation explained by single variables in unimproved wet grasslands were observed for northing, shrub cover, ground layer cover, elevation, easting and sapling height.

The differences in improved grassland plant community composition between planted and unplanted sites were driven by a management gradient along the first axis (Fig. 2). Axis 1 explained $13 \%$ of the total variability in the species data. It was positively correlated with sapling height, field layer height and litter cover, and negatively correlated with grazing. Axis 2 explained $7.6 \%$ of the variability and was most closely associated with elevation. There was a contrast between species typical of grassland characterised by intensive management (e.g. Lolium perenne, Taraxacum officinale agg., Bellis perenne, Trifolium spp., Cynosurus cristatus and Cerastium fontanum) on the left hand side of the ordination diagram in correspondence with the unplanted plots, and competitive grasses (e.g. Agrostis stolonifera, Arrhenatherum elatius, Deschampsia cespitosa and Elytrigia repens) and species that characterise abandoned pastures and field margins (e.g. Rubus fruticosus agg., Urtica dioica) on the right hand side of the ordination diagram, in association with the planted plots. Bryophyte species such as Fissidens bryoides, Thuidium tamariscinum and Lophocolea bidentata were also found in planted sites, related to management variables and to variables indirectly related to afforestation and grazing cessation (i.e. field height and shrub cover). 
Table 4 Variation explained by significant environmental and management variables in CCAs of mean species abundances in $4 \mathrm{~m}^{2}$ subplots in improved and unimproved wet grasslands

$T I$ total inertia, $I G$ improved grassland, $W G$ unimproved wet grassland, $M$ management variable, $E$ environmental variable

Significant variables were included by forward selection $(P \leq 0.05)$

\begin{tabular}{|c|c|c|c|}
\hline \multirow[t]{2}{*}{ Variable } & \multirow[t]{2}{*}{ Set } & \multicolumn{2}{|c|}{ Fraction of TI } \\
\hline & & IG & WG \\
\hline Ground layer cover & $\mathrm{E}$ & 0.030 & 0.048 \\
\hline Field layer height & $\mathrm{E}$ & 0.026 & - \\
\hline Shrub height & $\mathrm{E}$ & - & 0.034 \\
\hline Shrub cover & $\mathrm{E}$ & 0.047 & 0.059 \\
\hline Litter cover & $\mathrm{E}$ & 0.030 & - \\
\hline Easting & $\mathrm{E}$ & 0.021 & 0.044 \\
\hline Northing & $\mathrm{E}$ & - & 0.063 \\
\hline Slope & $\mathrm{E}$ & 0.036 & - \\
\hline Aspect & $\mathrm{E}$ & - & 0.027 \\
\hline Elevation & $\mathrm{E}$ & 0.062 & 0.055 \\
\hline K & $\mathrm{E}$ & - & 0.023 \\
\hline $\mathrm{Mg}$ & $\mathrm{E}$ & 0.034 & - \\
\hline Sapling height & M & 0.114 & 0.042 \\
\hline Sapling cover & M & 0.030 & - \\
\hline Grazing & M & 0.030 & 0.027 \\
\hline Drainage ditches & M & 0.039 & 0.029 \\
\hline
\end{tabular}

Planted and unplanted wet grassland plots from the same site pairs were separated along a management gradient, but the separation between them was not as defined as in improved grassland. One extreme of the management gradient included the more heavily grazed unplanted plots, whereas afforested plots containing drainage ditches and taller saplings were located towards the other extreme (Fig. 3). Axes 1 and 2 explained the same amount of variation in the species data equal to approximately $8 \%$. Axis 1 was positively correlated with northing and negatively correlated with drainage ditches while there were not variables which were specifically correlated with axis 2. Species like Agrostis stolonifera and Festuca rubra were positively related to the plantation management variables. Biogeographical and soil variables, such as northing and $\mathrm{K}$ concentration, were relatively more important in structuring plant communities in wet grasslands than in improved grasslands.

Variation partitioning between the environmental and management data sets is shown in Table 5. Environmental variables counted for $75 \%$ of the total variation explained in unimproved wet grassland subplots and approximately 55\% in improved grassland subplots. The contribution of management factors was similar between the two data sets and equal to approximately $25 \%$ of the TVE. In unimproved wet grassland plots, the small amount of variation accounted by both of the two sets of explanatory variables together indicated that the interaction between management and environmental variables was weak. In contrast, shared variation between the two sets of explanatory variables was considerable in improved grassland subplots and accounted for $20 \%$ of total variation explained.

Soils

Total nitrogen and calcium concentrations in improved grasslands were significantly higher in unplanted than in planted sites (Table 6). Soil $\mathrm{pH}$ was lower in the planted sites. There 


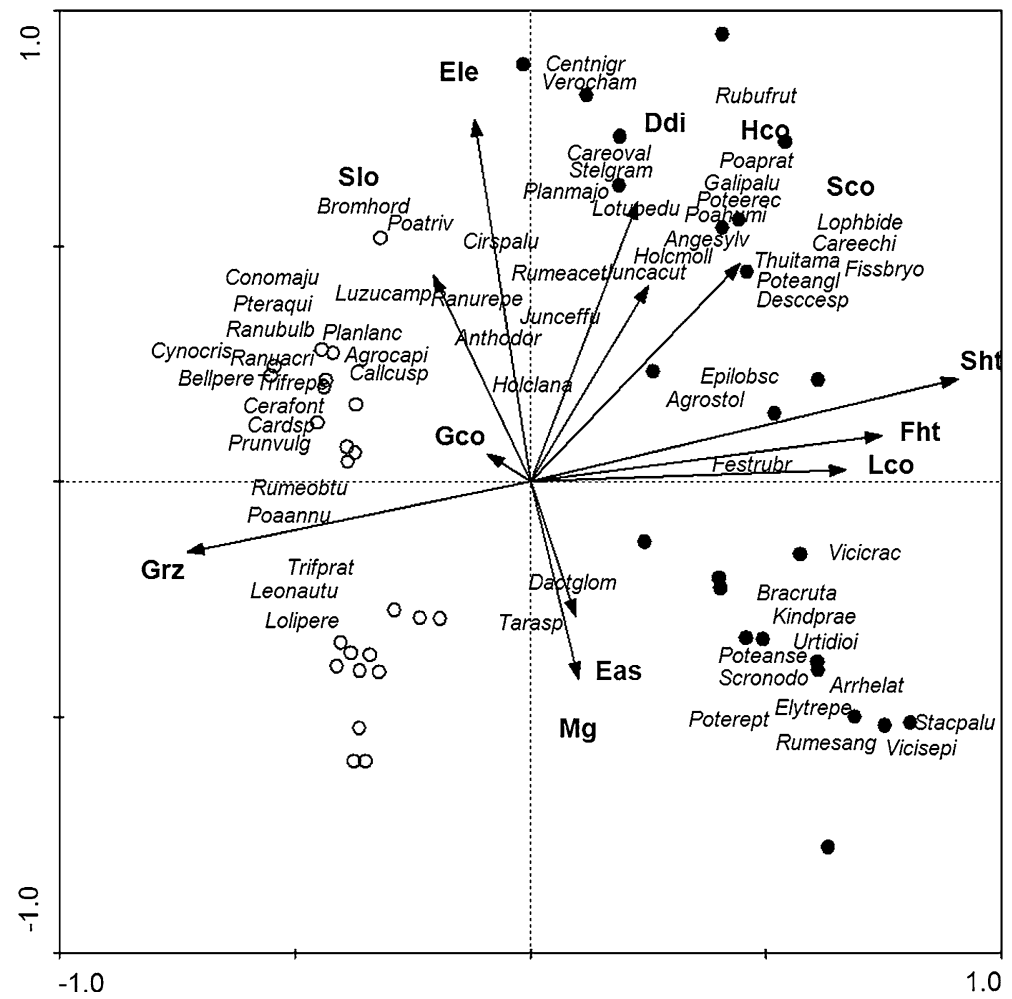

Fig. 2 Samples-species-explanatory variables triplot from CCA (axes 1 and 2) performed on improved grassland $4 \mathrm{~m}^{2}$ subplots: species fit range is between 3 and $100 \%$ (i.e. 82 species were reduced to 64 ). $\bigcirc=$ unplanted plots; - = planted plots; Gco = ground layer cover; Fht = field layer height; Hco = shrub cover; Lco = litter cover; Eas = easting; Slo = slope; Ele = elevation; $\mathrm{Mg}=$ magnesium; Sht = sapling height; Sco = sapling cover; $\mathrm{Grz}=$ grazing; Ddi = drainage ditches; agrocapi = Agrostis capillaries; agrostol = Agrostis stolonifera; angesylv = Angelica sylvestris; anthodor = Anthoxanthum odoratum; arrhelat = Arrhenatherum elatius; bellpere = Bellis $\quad$ perennis $; \quad$ bracruta = Brachythecium $\quad$ rutabulum $; \quad$ bromhord = Bromus hordeaceus; callcusp $=$ Calliergonella cuspidate $;$ cardsp $=$ Cardamine $\mathrm{sp}$; careechi $=$ Carex echinata ; careoval $=$ Carex ovalis; centnigr $=$ Centaurea nigra $;$ cerafont $=$ Cerastium fontanum $;$ cirspalu $=$ Cirsium palustre $;$ conomaju = Conopodium $\quad$ majus $; \quad$ cynocris = Cynosurus $\quad$ cristatus $; \quad$ dactglom = Dactylis $\quad$ glomerata $;$ desccesp = Deschampsia cespitosa $;$ elytrepe = Elytrigia repens; epilobsc = Epilobium obscurum; kindprae $=$ Kindbergia praelonga $;$ festrubr $=$ Festuca rubra $;$ fissbryo $=$ Fissidens bryoides $;$ galipalu $=$ Galium palustre $;$ holclana $=$ Holcus lanatus $;$ holcmoll = Holcus mollis; juncacut $=$ Juncus acutiflorus $;$ junceffu $=$ Juncus effusus; leonautu = Leontodon autumnalis; lolipere = Lolium perenne; lophbide = Lophocolea bidentata; lotupedu = Lotus pedunculatus; luzucamp = Luzula campestris; planlanc = Plantago lanceolata; planmajo $=$ Plantago major $;$ poaannu $=$ Poa annua $;$ poahumi $=$ Poa humilis $;$ poaprat $=$ Poa pratensis; poatriv $=$ Poa trivialis $;$ poteangl $=$ Potentilla anglica $;$ poteanse $=$ Potentilla anserine $;$ poteerec $=$ Potentilla erecta $;$ poterept $=$ Potentilla reptans $;$ prunvulg $=$ Prunella vulgaris; pteraqui $=$ Pteridium aquilinum; ranuac$\mathrm{ri}=$ Ranunculus acris; ranubulb = Ranunculus bulbosus; ranurepe = Ranunculus repens; rubufrut $=$ Rubus fruticosus agg.; rumeacet = Rumex acetosa; rumeobtu = Rumex obtusifolius; rumesang = Rumex sanguineus; scronodo $=$ Scrophularia nodosa $;$ stacpalu = Stachys palustris $;$ stelgram = Stellaria graminea $;$ tarasp $=$ Taraxacum sp.; thuitama $=$ Thuidium tamariscinum $;$ trifprat $=$ Trifolium pratense $;$ trifrepe $=$ Trifolium repens; urtidioi $=$ Urtica dioica , verocham $=$ Veronica chamaedrys $;$ vicicrac $=$ Vicia cracca $;$ vicisepi $=$ Vicia sepium

were also significant differences in organic carbon and litter cover percentage between planted and unplanted improved grasslands. No significant differences were found in soil properties between planted and unplanted wet grasslands, although the results indicate 


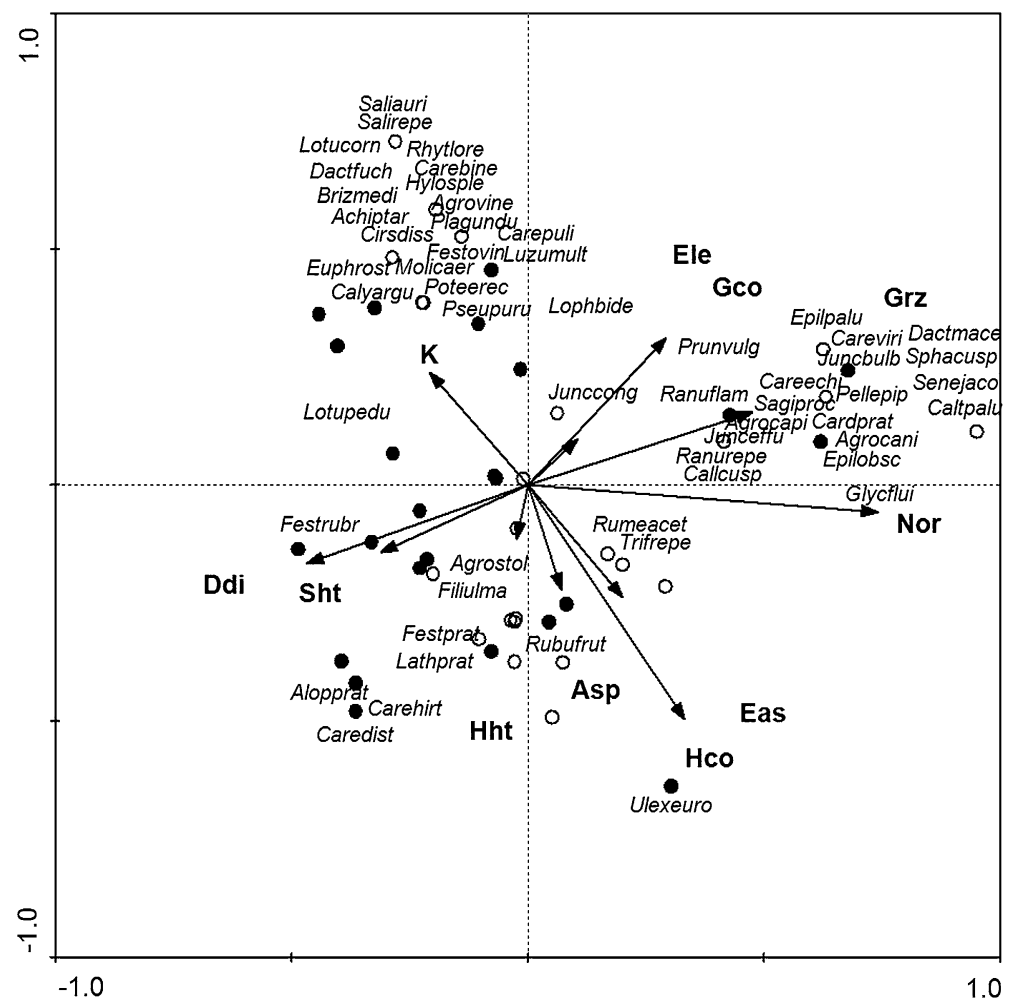

Fig. 3 Samples-species-explanatory variables triplot from CCA (axes 1 and 2) performed on unimproved wet grassland $4 \mathrm{~m}^{2}$ subplots: species fit range is between 7 and $100 \%$ (i.e. 126 species were reduced to 55). $\bigcirc=$ unplanted plots; $\bullet=$ planted plots; Gco = ground layer cover; Hht $=$ shrub height; Hco $=$ shrub cover; Eas = easting; Nor = northing; Asp = aspect; Ele = elevation; $\mathrm{K}=$ potassium; Sht = sapling height; Grz = grazing; Ddi = drainage ditches; achiptar = Achillea ptarmica , agrocaca = Agrostis canina subsp. canina; agrocapi = Agrostis capillaris; agrostol = Agrostis stolonifera $;$ agrovine = Agrostis vinealis; alopprat = Alopecurus pratensis; brizmedi = Briza media $;$ callcusp = Calliergonella cuspidata; caltpalu = Caltha palustris $;$ calyargu = Calypogeia arguta $;$ cardprat = Cardamine pratensis; carebine $=$ Carex binervis $;$ caredist $=$ Carex disticha $;$ careechi $=$ Carex echinata $;$ carehirt $=$ Carex hirta ; carepuli $=$ Carex pulicaris; careviri $=$ Carex viridula $;$ cirsdiss $=$ Cirsium dissectum; dactfuch $=$ Dactylorhiza fuchsii; dactmace = Dactylorhiza maculata supsp. ericetorum; epilobsc = Epilobium obscurum; epilpalu = Epilobium palustre $;$ euphrost = Euphrasia rostkoviana $;$ festovin = Festuca ovina; festprat = Festuca pratensis; festrubr = Festuca rubra; filiulma = Filipendula ulmaria $;$ glycflui $=$ Glyceria fluitans; hylosple = Hylocomium splendens; juncbulb = Juncus bulbosus; junccong = Juncus conglomeratus; junceffu = Juncus effusus; lathprat = Lathyrus pratensis; lophbide = Lophocolea bidentata; lotucorn = Lotus corniculatus; lotupedu = Lotus pedunculatus; luzumult = Luzula multiflora; molicaer = Molinia $\quad$ caerulea $; \quad$ pellepip = Pellia epiphylla $; \quad$ plagundu = Plagiomnium undulatum; poteerec $=$ Potentilla erecta $;$ prunvulg $=$ Prunella vulgaris $;$ pseupuru = Pseudoscleropodium purum; ranuflam $=$ Ranunculus flammula; ranurepe $=$ Ranunculus repens; rhytlore $=$ Rhytidiadelphus loreus; rubufrut = Rubus fruticosus agg.; rumeacet $=$ Rumex acetosa; sagiproc $=$ Sagina procumbens; saliauri $=$ Salix aurita $; \quad$ salirepe $=$ Salix repens $; \quad$ senejaco $=$ Senecio jacobaea $; \quad$ sphacusp $=$ Sphagnum cuspidatum; trifrepe $=$ Trifolium repens; ulexeuro $=$ Ulex europaeus

possible trends in calcium, nitrogen, organic carbon and litter cover percentage (Table 6). The difference in soil $\mathrm{pH}$ between unplanted and planted wet grasslands was almost significant $(p=0.06)$. 
Table 5 Variation partitioning of species data in $4 \mathrm{~m}^{2}$ plots in improved grasslands (IG) and wet grasslands (WG) between environmental (E) and management (M) explanatory variables using partial CCA

\begin{tabular}{|c|c|c|c|c|c|c|c|}
\hline \multicolumn{4}{|c|}{ Data set } & \multicolumn{4}{|c|}{ Fraction of TI } \\
\hline & $n_{\mathrm{E}}$ & $n_{\mathrm{M}}$ & TVE & $X$ & $\mathrm{E}$ & M & $\mathrm{S}$ \\
\hline IG & 8 & 4 & 0.498 & 0.502 & 0.273 & 0.125 & 0.100 \\
\hline WG & 8 & 3 & 0.454 & 0.546 & 0.342 & 0.102 & 0.010 \\
\hline
\end{tabular}

$S$ variation shared between $\mathrm{E}$ and $\mathrm{M}, X$ unexplained variation, $n_{\mathrm{E}}, n_{\mathrm{M}}$ number of significant variables from the $E$ and $M$ sets of explanatory variables used in each ordination, $T I$ total inertia

Table 6 Comparison of soil properties (mean \pm SEM) in unplanted (UP) and planted sites $(P)$ of improved grassland (IG) and unimproved wet grassland (WG) ( $n=8$ for each grassland type)

\begin{tabular}{|c|c|c|c|c|c|c|}
\hline & \multicolumn{3}{|l|}{ IG } & \multicolumn{3}{|l|}{ WG } \\
\hline & UP & $P$ & $p$-value & UP & $P$ & $p$-value \\
\hline $\mathrm{N}(\mathrm{mg} / \mathrm{L})^{\mathrm{a}}$ & $3,844 \pm 154$ & $3,235 \pm 164$ & 0.008 & $4,470 \pm 239$ & $4,229 \pm 133$ & 0.188 \\
\hline $\mathrm{P}(\mathrm{mg} / \mathrm{L})^{\mathrm{a}}$ & $734 \pm 67$ & $673 \pm 43$ & 0.394 & $552 \pm 38$ & $546 \pm 27$ & 0.896 \\
\hline $\mathrm{K}(\mathrm{mg} / \mathrm{L})^{\mathrm{a}}$ & $6,709 \pm 848$ & $7,494 \pm 795$ & 0.120 & $4,833 \pm 529$ & $5,240 \pm 506$ & 0.348 \\
\hline $\mathrm{Ca}(\mathrm{mg} / \mathrm{L})^{\mathrm{b}}$ & $8,063 \pm 3641$ & $2,935 \pm 854$ & 0.036 & $2,119 \pm 377$ & $1,582 \pm 250$ & 0.090 \\
\hline $\operatorname{Mg}(\mathrm{mg} / \mathrm{L})^{\mathrm{a}}$ & $2,458 \pm 360$ & $2,260 \pm 329$ & 0.276 & $1,675 \pm 129$ & $1,751 \pm 161$ & 0.484 \\
\hline $\mathrm{pH}^{\mathrm{a}}$ & $6.59 \pm \mathbf{0 . 3 0}$ & $6.04 \pm \mathbf{0 . 2 9}$ & 0.044 & $5.76 \pm 0.09$ & $5.50 \pm 0.14$ & 0.060 \\
\hline Organic $\mathrm{C}(\mathrm{mg} / \mathrm{L})^{\mathrm{b}}$ & $8,728 \pm 1001$ & $\mathbf{6 , 3 6 0} \pm 557$ & 0.030 & $11,184 \pm 1,001$ & $10,724 \pm 1120$ & 0.483 \\
\hline Litter cover $(\%)^{\mathrm{b}}$ & $2.79 \pm 0.70$ & $14.29 \pm 2.45$ & 0.012 & $6.67 \pm 1.52$ & $8.88 \pm 1.08$ & 0.164 \\
\hline
\end{tabular}

Significant differences among planted and unplanted sites are indicated in bold type Statistical tests: ${ }^{a} T$-test and the bon-parametric Wilcoxon's paired signed-ranks test

\section{Discussion}

Changes in vegetation following afforestation result from a series of factors, some of which are imposed quickly whilst others develop gradually; these may act simultaneously or sequentially (Sykes et al. 1989). The substantial differences in species richness, relative abundance and species composition observed between planted and unplanted sites were primarily due to removal of grazing, changes in nutrient management and drainage for afforestation. Wallace and Good (1995) studied the effects of afforestation on upland plant communities in England and found that in the early stages ( $<6$ years), stands tend to have poorly developed woodland flora; although cover may be high, the species present on mineral soils tend to be those characteristic of unmanaged sites. Sykes et al. (1989) reported the effects of reduced grazing and ground preparation following afforestation of upland grasslands. They found that grasses and rushes increase most in frequency, while species of wet habitats and small stature species become less frequent. These changes are similar to what we have found in lowland situations in this study.

In afforested improved grasslands, vigorous and competitive grasses commonly found in both wooded and unwooded habitats were significantly more frequent and less competitive ruderal species, which generally have open habitat affinities, were significantly less frequent than in unplanted sites. Analogous floristic changes were recorded in grasslands after the exclusion of grazing in other studies (Welch and Rawes 1964; Ball 1974; Stránská 2004). The first response to release from heavy grazing is a change in the structure of the 
community to one of greater height and more abundant tussocks; this is accompanied by a change in the competitive balance between species, with the gradual loss of some species, increase in others and invasion of new species (Ball 1974). The higher bryophyte species richness found in planted improved grasslands suggests they have colonised the new habitat under the shade of the taller ungrazed grasses. Some colonising species may be present in the soil bank or may invade from neighbouring vegetation (Stránská 2004). Surrounding habitats, such as hedgerows and other ecological corridors like rivers and road banks, represent a potential resource of species which may be able to colonise the newly afforested areas. In this study, a decrease in grazing pressure allowed highly competitive species, such as Rubus fruticosus and Arrhenatherum elatius, to colonise the grassland from neighbouring hedgerows. In many cases, this may lead to a species-poor community mostly dominated by vigorous grasses. However, improved grasslands are themselves species-poor habitats, and therefore afforestation of these habitats will have little shortterm impact on biodiversity.

In unimproved wet grasslands, changes were similar but less marked if compared with improved grasslands, because of generally lower pre-afforestation grazing pressures and fertilisation. Drainage contributed to the decrease in species preferring wet conditions and also to the increases in competitive species. Drainage ditches were responsible for the discrepancies between plot scales in species richness differences between planted and unplanted wet grasslands. They were included in $100 \mathrm{~m}^{2}$ plots, but not $4 \mathrm{~m}^{2}$ plots, and provided new, reduced-competition habitats for bryophytes and pioneer vascular plant species such as Riccardia chamaedryfolia and Carex viridula. This accounts for the lack of a difference in species richness at the $100 \mathrm{~m}^{2}$ scale while species richness at the $4 \mathrm{~m}^{2}$ was lower in planted sites due to greater competitive pressures.

Variation between the floristic composition of unplanted and planted grassland is related to both natural variability and forestry induced changes, including changes in drainage, ground preparation and shading by trees (Wallace and Good 1995). In this study, the relative importance of explanatory variables differed between improved grassland and unimproved wet grassland plots. Environmental variables explained a higher fraction of the variation in unimproved wet grasslands (75.3\%) than in improved grasslands $(54.8 \%)$. This difference is best explained by the higher variation in environment among unimproved wet grassland sites. The low percentage of shared variation $(2.2 \%)$ between environmental and management variables in unimproved wet grasslands showed that the two sets of explanatory variables were weakly correlated. On the other hand, in improved grasslands environmental variables accounted for $25 \%$ of the variation, and the two sets of variables shared $20 \%$ of the total variance explained, showing that the effects of afforestation and the consequent cessation of grazing on vegetation communities were apparently greater in improved grasslands than in wet grasslands. This finding is reflected by differences in soil properties which were found only for improved grasslands, where plantations had lower total nitrogen, calcium and organic carbon and higher soil acidity. Although it is possible that some of these differences in soil chemistry between paired sites were present prior to afforestation, studies examining the shift of native grassland to forest reveal various degrees of surface soil acidification after conifer establishment (Page 1968; Hornung 1985; Reich et al. 2005).

The decline in $\mathrm{pH}$ may be associated with the loss of exchangeable cations, particularly $\mathrm{Ca}$, organic acid inputs and increased soil respiration (Page 1968; Hornung 1985; Jobbágy and Jackson 2003), and accumulation of cations in tree biomass (Hornung 1985; Parfitt et al. 1997). In the present study, where the trees were still small, it is unlikely that the acidification was due to tree nutrient uptake. The $\mathrm{pH}$ decrease may therefore be linked to 
lower soil $\mathrm{Ca}$ after afforestation and/or to organic acid inputs which enter the soil predominantly from the surface, causing maximum acidification in the topsoil. As litter percentage cover increased significantly under Picea sitchensis differences in $\mathrm{pH}$ levels between unplanted and planted sites in this study could also have been caused by differences in quantity and quality of litter, litter decomposability and microbial activity.

Lower nitrogen in afforested sites could be explained by several factors including the accumulation of nitrogen in tree biomass which is expected to be greatest within the first 15 years of plantation (Gholz et al. 1985), denitrification (loss of total N) and leaching of $\mathrm{N}$ due to enhanced mineralisation/nitrification (Parfitt et al. 1997). In this study, most improved grassland sites had previously been fertilised annually with synthetic N-P-K fertilisers and/or animal manure. Fertiliser applications ceased after afforestation, leading to a temporal gradient of decreasing fertility which may represent a further explanation for the observed difference in total nitrogen.

Concentrations of soil organic C in topsoil were significantly lower under Sitka spruce compared with unplanted improved grassland. The causes of changes in soil organic carbon when land use is changed may be ascribed to soil disturbance through ploughing or ripping, clearing of the original vegetation and control of competing vegetation in the initial years (Turner and Lambert 2000). Other important factors affecting soil carbon are previous land uses, climate, soil texture, site management, type of forest established (Polglase et al. 2000), and low production of detrital materials (e.g. litterfall, root turnover) in the early stages of stand development (Parfitt et al. 1997).

The absence of significant differences between unplanted and planted sites in unimproved wet grasslands might be due to the greater organic matter content and consequent buffering capacity of the wet soils, to the clay texture, to water logging conditions which could have delayed the effects of conversion between grasslands and plantation, and to a lower fertilisation rate of pre-afforested sites. In addition, variability in soil chemistry among wet grassland site pairs probably obscures differences between planted and unplanted sites.

\section{Conclusions}

The initial effects of afforestation appeared to be largely the results of three factors: exclusion of grazing, forestry drainage and changes in nutrient management. The impacts of afforestation on vegetation and soil properties of the studied habitats were greater in improved grasslands than in wet grasslands. Species sensitive to shading declined under competitive pressure from vigorous grasses and other aggressive colonist species. Drainage ditches provided a temporary habitat for new pioneer and less competitive species, but the overall effect of drainage contributed to a reduction in species richness and diversity. Planted improved grasslands had lower total nitrogen, calcium, organic carbon and $\mathrm{pH}$ than unplanted grasslands; these differences may be the result of ground preparation for afforestation and the effects of conifer litter, but it is impossible to rule out pre-existing differences. Any changes may have been lessened in wet grassland by several factors, e.g. soil texture and poor drainage. Since afforestation of these sites occurred only 5 years ago - a short period compared with the age of a mature forest-more changes may be expected to occur in the next few years. The tree saplings were still small, and the planted habitats were still grasslands rather than woodlands. When the trees become more mature and form a closed canopy, the understorey vegetation will be almost completely eliminated if it is a densely shading species such as Sitka spruce (Hill 1979; French 2005). Because of 
its short- and long-term effects, we conclude that afforestation will have a detrimental effect on semi-natural habitats. Such habitats, such as semi-natural wet grasslands, should not be afforested, unless similar habitats are abundant in the landscape. On the other hand, the effect of afforestation on improved and semi-improved grasslands will be neutral or positive, particularly in landscapes that contain little semi-natural woodland habitat.

Acknowledgements This research is a product of the BIOFOREST project, which is funded by the Council for Forest Research and Development (COFORD) and the Environmental Protection Agency (EPA) under the Irish National Development Plan 2000-2006. The authors acknowledge Dr Laura French, Ms Linda Coote, Ms Aoife Delaney and Ms Jacqueline Bolli for assistance in the field and with database management, and two anonymous referees for valuable comments on this paper. Thanks are also due to the Portuguese Foundation for Science and Technology (FCT) for grant aiding E.B.'s work (SFRH/BM/12697/ 2003).

\section{References}

Alard D, Bance JF, Frileux PN (1994) Grassland vegetation as an indicator of the main agro-ecological factors in a rural landscape: consequences for biodiversity and wildlife conservation in central Normandy (France). J Environ Manage 42:91-109

Alfredsson H, Condron LM, Clarholm M, Davis MR (1998) Changes in soil acidity and organic matter following the establishment of conifers on former grassland in New Zealand. For Ecol Manage 112:245-252

Ball ME (1974) Floristic changes on grasslands and heaths on the isle of Rhum after a reduction or exclusion of grazing. J Environ Manage 2:299-318

Berthelot MPE (1859) Violet d'aniline. Repert Chim Appl 1:284

Borcard D, Legendre P, Drapéau P (1992) Partialling out the spatial component of ecological variation. Ecology 73:1045-1055

Byrne C, Kelly DL, Jeffrey DW (1997) An experimental study of floristic composition in semi-natural grassland in eastern Ireland. In: Proceedings of the international occasional symposium of the European Grassland Federation, Warszawa, Łomża, Poland, 19-23 May 1997

Curtis TGF, McGough HN (1988) The Irish red data book. 1. Vascular plants. Stationery Office, Dublin

Department of Agriculture Food, Forestry (1996) Growing for the future: a strategic plan for the development of the forestry sector in Ireland. Stationery Office, Dublin

Elemans M (2004) Light, nutrients and the growth of the herbaceous forest species. Acta Oecol 26:197-202

European Commission (1999) Interpretation Manual of European Union Habitats. EUR 15/2. DG Environment

Fahy O, Gormally M (1998) A comparison of plant and carabid beetle communities in an Irish oak woodland with a nearby conifer plantation and clearfelled site. For Ecol Manage 110:263-273

Farley KA, Kelly EF (2004) Effects of afforestation of a páramo grassland on soil nutrient status. For Ecol Manage 195:281-290

Ferris R, Peace AJ, Humphrey JW, Broome AC (2000) Relationships between vegetation, site type and stand structure in coniferous plantations in Britain. For Ecol Manage 136:35-51

Forest Service (2000) Forest biodiversity guidelines. Department of the Marine and Natural Resources, Dublin

Forest Service (2004) Forestry statistics. Department of Agriculture and Food, Dublin. http://www. agriculture.gov.ie/forestry/files/standard.xls

Fossitt JA (2000) A guide to habitats in Ireland. The Heritage Council, Dublin

French L (2005) Ground flora communities in Ireland's plantation forests: their diversity, structure and composition. PhD thesis, University of Dublin, Trinity College, Dublin

Gardiner MJ, Radford T (1980) Soil associations of Ireland and their land use potential. An Foras Taluntais, Dublin

Gholz HL, Fisher RF, Pritchett WL (1985) Nutrient dynamics in slash pine plantation ecosystems. Ecology 66:647-659

Heritage Council (1999) Forestry and the National Heritage. Policy paper. Kilkenny, Ireland

Hill MO, Jones EW (1978) Vegetation changes resulting from afforestation of rough grazing in Caeo forest, south Wales. J Ecol 66:433-456 
Hill MO (1979) The development of a flora in even-aged plantations. In: Ford ED, Malcolm DC, Atterson J (eds) The ecology of even-aged forest plantations. Institute of Terrestrial Ecology, Cambridge, pp 175192

Hochberg Y (1988) A sharper Bonferroni procedure for multiple tests of significance. Biometrika 75:800802

Holyoak D (2003) The distribution of bryophytes in Ireland. Broadleaf Books, Dinas Powys

Hornung M (1985) Acidification of soils by trees and forests. Soil Use Manage 1:24-28

Jeffrey DW (1970) A note on the use of ignition loss as a means for the approximate estimation of soil bulk density. J Ecol 58:297-299

Jobbágy EG, Jackson RB (2003) Pattern and mechanisms of soil acidification in the conversion of grasslands to forests. Biogeochemistry 64:205-229

Jobbágy EG, Jackson RB (2004) The uplift of soil nutrients by plants: biogeochemical consequences across scales. Ecology 85:2380-2389

Legendre P, Legendre L (1998) Numerical ecology. Elsevier Science BV, Amsterdam

MCPFE (2003) State of Europe's forests 2003. MCPFE Liason Unit, Vienna

Murphy J, Riley JP (1962) A modified single solution method for the determination of phosphate in natural waters. Anal Chim Acta 27:31-36

Økland RH, Eilertsen O (1994) Canonical correspondence analysis with variation partitioning: some comments and an application. J Veg Sci 5:117-126

Page G (1968) Some effects of conifer crops on soil properties. Commonw For Rev 47:52-62

Parfitt RL, Percival HJ, Dahlgren RA, Hill LF (1997) Soil and solution chemistry under pasture and radiata pine in New Zealand. Plant Soil 191:279-290

Paton JA (1999) The liverwort flora of the British Isles. Harley Books, Colchester

Pielou EC (1975) Ecological diversity. Wiley, New York

Polglase PJ, Paul KI, Khanna PK, Nyakuengama JG, O'Connell AM, Grove TS, Battaglia M (2000) Change in soil carbon following afforestation or reforestation. National carbon accounting system. Technical Report No. 20. Australian Greenhouse Office, Canberra

Reich PB, Oleksyn J, Modrzynski J, Mrozinski P, Hobbie SE, Eissenstat DM, Chorover J, Chadwick OA, Hale CM, Tjoelker MG (2005) Linking litter calcium, earthworms and soil properties: a common garden test with 14 tree species. Ecol Lett 8:811-818

Smith AJE (2004) The moss flora of Britain and Ireland. Cambridge University Press, Cambridge

Smith B, Wilson JB (1996) A consumer's guide to evenness indices. Oikos 76:70-82

Sokal RR, Rohlf FJ (1995) Biometry, 3rd edn. WH Freeman and Co, New York

SPSS (2003) SPSS 12.0 for Windows. SPSS, Chicago

Stace C (1997) New flora of the British Isles. Cambridge University Press, Cambridge

Stránská M (2004) Successional dynamics of Cynosurus pasture after abandonment in Podkrkonoší. Plant Soil Env 50:364-370

Sykes JM, Lowe VPW, Briggs DR (1989) Some effects of afforestation on the flora and fauna of an upland sheepwalk during 12 years after planting. J Appl Ecol 26:299-320

ter Braak CJF, Smilauer P (2002) CANOCO reference manual and CanoDraw for Windows user's guide: software for Canonical Community Ordination (version 4.5). Microcomputer Power, Ithaca

ter Braak CJF (1986) Canonical correspondence analysis: a new eigenvector technique for multivariate direct gradient analysis. Ecology 67:1167-1179

Turner J, Lambert M (2000) Change in organic carbon in forest plantation soils in eastern Australia. For Ecol Manage 133:231-247

Wallace HL, Good JEG (1995) Effects of afforestation on upland plant communities and implications for vegetation management. For Ecol Manage 79:29-46

Wallace HL, Good JEG, Williams TG (1992) The effects of afforestation on upland plant communities: an application of the British National Vegetation Classification. J Appl Ecol 29:180-194

Welch D, Rawes M (1964) The early effects of excluding sheep from high-level grasslands in the north Pennines. J Appl Ecol 1:281-300

Wulf M (2004) Plant species richness of afforestations with different former use and habitat continuity. For Ecol Manage 195:191-204 